NBER WORKING PAPER SERIES

\title{
CATCHING-UP TO FOREIGN TECHNOLOGY? EVIDENCE ON THE "VEBLEN-GERSCHENKRON" EFFECT OF FOREIGN INVESTMENTS
}

\author{
Giovanni Peri \\ Dieter Urban \\ Working Paper 10893 \\ http://www.nber.org/papers/w10893
}

\author{
NATIONAL BUREAU OF ECONOMIC RESEARCH \\ 1050 Massachusetts Avenue \\ Cambridge, MA 02138 \\ November 2004
}

Urban gratefully acknowledges financial support from the European Commission Fifth Framework Programme (Grant No. FMRX-CT-0215). We owe particular thanks to Deutsche Bundesbank for providing us with unpublished regional data on foreign owned firms in Germany. We thank an anonymous referee and John Quigley for useful comments. Giorgio Barba Navaretti and Steve Redding also provided helpful suggestions. Arturo de Visdomini provided excellent research assistance. Errors are ours. The views expressed herein are those of the author(s) and not necessarily those of the National Bureau of Economic Research.

(C) 2004 by Giovanni Peri and Dieter Urban. All rights reserved. Short sections of text, not to exceed two paragraphs, may be quoted without explicit permission provided that full credit, including $\odot$ notice, is given to the source. 
Catching-Up to Foreign Technology? Evidence on the Veblen-Gerschenkron" Effect of Foreign Investments

Giovanni Peri and Dieter Urban

NBER Working Paper No. 10893

November 2004

JEL No. F23, O47, R11

\begin{abstract}
The presence of foreign multinational enterprises may benefit local economies. In particular, highly productive foreign-owned firms may promote technological catch-up of local firms. Such channel of spillovers is defined as "Veblen-Geschenkron" effect of Foreign Direct Investments and is analyzed in this article. Rather than the overall density of foreign-owned plants in a region or sector, it is their productivity advantage that determines the positive effect on domestic firms in geographical and technological proximity. We test this hypothesis using new firm-level data for German and Italian manufacturing firms during the 90's. We find evidence of a significant VeblenGerschenkron effect which is robust to different ways of measuring total factor productivity (TFP) of firms and to different empirical specifications.
\end{abstract}

Giovanni Peri

Department of Economics

University of California, Davis

One Shields Avenue

Davis, CA 95616

and NBER

gperi@ucdavis.edu

Dieter Urban

Institute for International Economic Theory

Johannes Gutenberg University of Mainz 55099 Mainz, Germany

durban@uni-mainz.de 


\section{Introduction}

Do foreign direct investments (FDI) benefit domestic firms of the host country? If they do, what are the channels of these effects? These long standing and important questions have attracted much interest among economists. On the theoretical ground FDI may help or harm domestic firms depending on the intensity of different effects. Ultimately the net effect of FDI has to be evaluated empirically, and recent empirical studies have found effects ranging from positive to negative, depending on the focus, the data and the method used ${ }^{1}$. This article contributes another piece of evidence to this issue by focussing on a potentially important (but somewhat neglected) determinant of spillovers from FDI to domestic firms ${ }^{2}$, namely the productive advantage of foreign firms over domestic firms within a sector and region.

According to Blomström et al. (2001) "foreign investors make available (directly or indirectly) appropriable technology to host country businesses. Appropriable technology should be viewed broadly as any tangible or intangible resource that can generate economic rent for host country firms, ... by improving total factor productivity." Technological spillovers, therefore, should depend on the technological advantage of the foreign firms and on their geographical proximity to the domestic firms. Hence, our variable of interest will be the productivity advantage of foreign-owned firms over domestic firms in a sector-region. Since the work of Caves (1974) economists have focussed their attention on the concentration of foreign-owned firms (measured as the share of FDI capital or share of FDI workers) within a sector and/or a region as the source (and proxy) of potential spillovers ${ }^{3}$. Recently, however, Aitken and Harrison (1999) have shown that properly controlling for unobserved region-specific effects eliminates most of the effect of FDI density on domestic firms' productivity. This may occur because some local characteristics that attract $\mathrm{FDI}^{4}$ (such as the presence of highquality labor force, large local markets, good infrastructures and good administration) also enhance

\footnotetext{
${ }^{1}$ Advocates of a positive role of FDI through technological transfer are Findlay (1978), Das (1987), and Wang and Blomström (1992). Rodriguez-Clare (1993) and Markusen and Venables (1999) argue that they benefit local suppliers and local consumers. Fosfuri et al. (2001), and Glass and Saggi (1998, 2002) document that they could increase the human capital of the local labor force. On the other hand, FDI could out-compete local firms forcing them out of production without employing local labor because of skill mis-match. This is argued in Aitken and Harrison (1999).

${ }^{2}$ For a survey of the literature see Blomström and Kokko (1998). An interesting meta-analysis of the different research results is Görg and Strobl (2001).

${ }^{3}$ There have been some studies aimed at quantifying some important channels of knowledge diffusion via FDI. Branstetter (2001) uses patent citation data while Cassiman and Veugelers (2002) rely on survey data. These studies, however, address specific channels of spillovers rather than their overall impact on productivity.

${ }^{4}$ See, for example, Shannon and Zeile (1999) for the US and Stirböck (2001) for Europe.
} 
the productivity of domestic firms generating a spurious correlation between the two variables. Once these factors are properly controlled for, no correlation survives.

This result, however, does not necessarily imply zero spillovers from FDI. Instead the density of FDI may not be the right source of (and proxy for) spillovers. The productivity advantage of foreign firms is potentially a more important source of spillovers. While the largest concentration of foreign firms occurs, normally, in regions and sectors where domestic firms are already highly productive, the largest effect of foreign firms on domestic ones could be in backward regions, where concentration of FDI is small, but their effect is large as the scope for technological catch-up is large. The operating of this mechanism is named, extending an early intuition by Veblen (1915) and Gerschenkron (1952), the "Veblen-Gerschenkron" effect.

The original hypothesis, formalized by Findlay (1978), states that technologically disadvantaged regions are more likely to benefit from spillovers of FDI and may experience, as a consequence, stronger productivity growth relative to advanced regions. The hypothesis tested in this article, using a new dataset of domestic and foreign-owned manufacturing firms in Italy and Germany for the period 1993-1999, is that the productivity gap between domestic firms and foreign-owned firms (in the same sector and region) is an important determinant of domestic firms' productivity growth. The positive effect of the productivity gap on subsequent productivity growth of domestic firms will be referred to as Veblen-Gerschenkron effect. On one hand some recent studies (Haddad and Harrison, 1993; Kokko, 1994; Sjöholm, 1999; Castellani and Zanfei, 2003) have emphasized beneficial effects from FDI's on domestic firms due to intra-industry technology spillovers and subsequent catch-up. On the other hand, studies on the diffusion of technological knowledge based on patent and innovation data (Jaffe et al. 1993; Audretsch and Feldman 1996; Peri 2004) have emphasized the high degree of localization of these flows. Our analysis is the first to combine the regional dimension of spillovers from FDI with the importance of the productivity-gap in generating them. Such a method allows us to identify the Veblen-Gerschenkron effect while controlling for sector-specific determinants of spillovers.

A second novel contribution of our study is the computation and use of as many as five measures of total factor productivity at the firm level, each based on a different method and different assumptions. As measures of total factor productivity are always indirect, i.e. based on the calculation of a "residual" from the production function, they can be polluted by systematic unobserved 
errors. In particular, our measures of firm-level TFP address three important problems namely endogeneity of foreign ownership, unobserved heterogeneity of firms and selection in the sample. Each one of the methods used is more appropriate in addressing some rather than others among these issues. The fact that using any of our TFP measures we find robust and similar estimates of the Veblen-Gerschenkron effect substantially reduces our concerns for spurious results.

Finally our paper, differently from others, focuses on the interesting case of Germany, after reunification vis-a-vis the problematic Italian case of long-standing regional disparities as hostcountries for FDI's. Our new dataset contains geographic identifiers that allow us to locate firms within one of 103 Provinces, for Italian data, and within one of 16 Regions (Bundeslanders) for German data. Italy and Germany have well-known issues of uneven regional development and the cross-sectional variation of productivity across firms is large. Our study exploits these differences and provides some evidence on the role of foreign investments in promoting productivity catch-up in less developed regions. In particular, Germany is a very interesting case-study as the unification and subsequent inflow of firms from Western Europe put eastern firms in touch with new technologies after fifty years of isolation. East German firms after the unification exhibited substantial technological backwardness when a sudden inflow of western firms occurred, generating the ideal conditions for a strong Veblen-Gerschenkron effect.

Our estimates show the presence of a positive and significant Veblen-Gerschenkron effect using each one of our measures of productivity. Such effect is large and of similar magnitude for German and Italian firms. We interpret this as evidence that the presence of highly productive FDI (considered as exogenous to domestic firms) has a stimulating effect on productivity growth of local firms.

The rest of the article is organized as follows. Section 2 describes our empirical model and the estimation strategy. Section 4 describes the data for Germany and Italy, Section 5 presents the estimates, with particular emphasis on the Veblen-Gerschenkron effect. Section 6 concludes the article. 


\section{TFP dynamics}

We allow total factor productivity (TFP) of sector $s$ in year $t$ to follow a (deterministic or stochastic) growth path that depends on structural determinants that may vary by sector and year. Calling $A_{i, r, s, t}$ the (logged) difference between firm $i^{\prime} s$ TFP and the average TFP in sector $s$ and year $t$, we can describe the dynamics of this variable as follows:

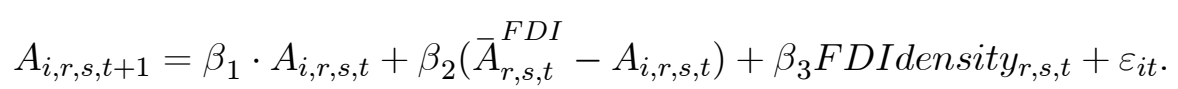

$A_{i, r, s, t+1}$ depends on its lagged level $A_{i, r, s, t}$ and on two other factors. One, FDIdensityr,s,t , is the concentration of foreign owned firms in the same sector and region and is the classic term included to capture spillovers from FDI. The variable FDIdensity ${ }_{r, s, t}$, is measured as the share of workers employed in foreign-owned firms in region $r$ and sector $s$ at time $t$. The other, $\left(\bar{A}_{r, s, t}^{F D I}-A_{i, r, s, t}\right)$, is a measure of the technological (TFP) advantage of the foreign-owned firms on local domestic firms. In particular it is measured as the difference between the TFP of the domestic firm $i$ and the average TFP of foreign firms in the same region $r$ and sector $s$ for year $t$. As discussed above, this term captures the scope for productive catch-up of domestic firms assuming that they have an adequate absorptive capacity ${ }^{5}$ and that geographycal proximity enhances spillovers. Notice that if there are no localized spillovers but only an homogeneous externality on all firms in the sector, the regional gap variable will have no effect as we control for sector-time dummies.

Equation (1) is a dynamic version of a very common specification used (e.g. by Aitken and Harrison, 1999) to analyze the effect of FDI on domestic firms' productivity. The relevant differences are the dynamic setting, more appropriate to detect effects that materialize with a delay and the inclusion of the term capturing the technological advantage of the foreign-owned firms operating in region $r$ and sector $s^{6}$.

Several assumptions may justify the presence of this term in equation (1). Domestic firms may come in contact with other technologies randomly in a learning process. The geographical proximity of technologies used by foreign firms and their relative quality both influence positively

\footnotetext{
${ }^{5}$ For countries with low level of human capital a measure of average local schooling could proxy their absorptive capacity (see, for example, Keller 1996, Glass and Saggi, 1998, Kinoshita 2001). Germany and Italy guarantee adequate levels of literacy and we assume equal absorptive capacity across provinces for a given technological gap.

${ }^{6}$ The theoretical foundation for the dynamic specification can be found in Findlay (1978).
} 
the learning rate of a domestic firm. If we think, for instance, that workers from a domestic firm exchange ideas randomly with workers of foreign-owned firms then the frequency of the exchanges is positively affected by geographic proximity (hence the choice of regional focus) while the amount of knowledge exchanged depends on the technological gap (hence the inclusion of the productivity gap). This is why highly productive FDI in the same region and sector may affect domestic firm's productivity. Alternatively, technology from foreign owned firms may be a local public good. Then, the localized diffusion of technology (Jaffe et al. 1993) and higher quality of such technology (average productivity of FDI's) result in a localized Veblen-Gerschenkron effect ${ }^{7}$. While it can be hard to distinguish between specific mechanisms, here we need only identify the overall effect of the "local productivity gap" and its empirical relevance for productivity growth of domestic firms.

Considering the productivity advantage of foreign-owned firms as exogenous we can estimate the above equation using dynamic panel methods (such as those proposed by Arellano and Bond, 1991, or Blundell and Bond, 1998). The coefficient $\beta_{2}$ captures the strength of the Veblen-Gerschenkron effect (which is the focus of our study) while the coefficient $\beta_{3}$ measures the importance of FDI concentration. As we control for lagged productivity, the regression also provides information on the conditional convergence behavior of firm's productivities to a common sector-specific growth path. The condition for convergence (stationarity of the $A_{i, r, s, t}$ series) is that the coefficient on lagged productivity $\left(\beta_{1}-\beta_{2}\right)$ is smaller than one. In the empirical analysis we will test for stationariety of $A_{i, r, s, t}$ and we will check that the estimates of $\left(\beta_{1}-\beta_{2}\right)$ are significantly less than one. Finally, $\varepsilon_{i t}$ is an i.i.d. random shock. For future reference, we will call the variable $\left(\bar{A}_{r, s, t}^{F D I}-A_{i, r, s, t}\right)$ the "Productivity Gap".

Equation (1) has several potential advantages relative to the standard approach to FDI spillovers. First, factors that vary with sector and time are fully absorbed by the definition of $A_{i, r, s, t}$ that captures only the productivity difference of a firm from the sector-time average. Second, regional factors that affect TFP levels of both domestic and foreign firms do not bias the estimates of $\beta_{2}$ because the "Productivity Gap" variable is expressed in log-difference and therefore independent from productivity levels. Third, omitted factors that may attract FDI do not bias the estimate

\footnotetext{
${ }^{7}$ An alternative possibility in the case of technology as a local public good is that the relevant productivity gap is between the domestic firm and the most-productive FDI. Work by Girma and Görg (2004) consider this possibility. In practice, however, the measure of the most productive FDI, based on one observation only, can be very noisy and less reliable than average productivity of FDI's.
} 
of $\beta_{2}$ because we control for FDIdensityr,s,t. The effect of such variables is captured by the coefficient $\beta_{3}$. Lastly, this specification enables us to separate a spillover effect from a competition effect. According to Barrios et al. (2004) foreign owned firms drive up wages through their labor demand and this forces domestic firms to reduce their employment which in turn increases their productivity. Such effect is probably due mostly to the presence of foreign firms (rather than to their productivity) and therefore captured by $\beta_{3}$. Moreover we can control for this effect by adding employment growth of domestic firms which would capture the cutting of inefficient jobs. We do this in section 5.4 .

\section{$3 \quad$ Measuring Total Factor Productivity}

In order to estimate equation (1), the TFP of firms needs to be measured. As TFP cannot be observed but it is always calculated as a "residual" from a production function estimation, different assumptions on production and different estimation methods may produce different estimates. Here we take the approach of using several different methods to measure $A_{i, r, s, t}$ and we use each of these measures to estimate equation (1). In particular, we use one measure of TFP based on a superlative index and four measures based on production function estimation, two of which are more standard (OLS and fixed effects) and two of which are concerned with non-standard issues (Levinsohn and Petrin 2003 and efficient frontier). The robustness of the results obtained using each set of measures reinforces our confidence in the estimated effect. We present each of these methods in the rest of this section.

\subsection{Total Factor Productivity via Superlative Index Number}

We first measure TFP using a superlative index number as derived in Caves, Christensen, and Diewert (1982). This index assumes a translogarithmic production function, constant returns to scale in production and uses data on factor cost shares. In particular, we define the TFP of a firm $i$ relative to the average productivity of sector $s$ at time $t, A_{i, r, s, t}^{\text {sup }}$ as:

$$
A_{i, r, s, t}^{\mathrm{sup}}=\left(y_{i, r, s, t}-\bar{y}_{s, t}\right)-\frac{\alpha_{i, r, s}+\bar{\alpha}_{s}}{2}\left(k_{i, r, s, t}-\bar{k}_{s, t}\right)
$$

In the expression above $y_{i, r, s, t}$ is the natural logarithm of value added per worker (value of 
sales net of material cost) for firm $i$ in region $r$, sector $s$ and year $t . \bar{y}_{s, t}$ is the average value of $y_{i, r, s, t}$ for all firms in sector $s$ and year $t . \alpha_{i, r, s}$ is the elasticity of output to physical capital of firm $i$. Assuming constant return to scale in production and profit maximization behavior, $\alpha_{i, r, s}$ is measured by one minus the share of labor costs in value added for firm $i$. The parameter $\bar{\alpha}_{s}$ is one minus the average share of capital costs in sector $s . k_{i, r, s, t}$ is the natural logarithm of capital per worker in firm $i$ in region $r$, sector $s$ and year $t$ and $\bar{k}_{s, t}$ is the average of $k_{i, r, s, t}$ for all firms in sector $s$ and year $t$. Subtracting the averages is equivalent to controlling for sector-time specific factors that affect TFP. Using this method TFP is calculated, not estimated and no standard erros are produced. Hence, the only two types of errors involved are potential mistakes in the firm balance sheet data and violations of the theoretical assumptions.

\subsection{Total Factor Productivity via Production Function Estimation}

As an alternative, it is possible to identify the relative TFP of firms through direct estimation of the production function. We maintain the assumption of constant return to scale of output to capital and labor ${ }^{8}$. However, rather than relying on cost shares we can directly estimate the elasticity of value added to capital. We indicate with $A_{i, r, s, t}^{\text {prod }}$ the measure of firm $i^{\prime} s$ TFP in region $r$ sector $s$ and year $t$ relative to the sector-year average. In this case, we estimate the following equation:

$$
y_{i, r, s, t}-\bar{y}_{s, t}=\alpha_{s}\left(k_{i, r, s, t}-\bar{k}_{s, t}\right)+\beta_{s} F_{i, r, s, t}+A_{i, r, s, t}^{\text {prod }}+\varepsilon_{i, r, s, t}
$$

The coefficient $\alpha_{s}$ captures the elasticity of output to physical capital and it is allowed to vary by sector, implying different technologies across sectors. $F_{i, r, s, t}$ is a dummy variable equal to one if the firm is foreign-owned and zero otherwise. Some firms change ownership during the sample period as they are acquired by multinational corporations, so that $F_{i, r, s, t}$ for a given firm $i$ may change over time. The coefficient $\beta_{s}$ captures the effect on productivity of foreign ownership. Similarly to the previous method, sector-time fixed effects are taken into account by "netting" the group mean from each variable.

The term $\left(A_{i, r, s, t}^{\text {prod }}+\varepsilon_{i, r, s, t}\right)$ accounts for the remaining productivity of firm $i$. The term $A_{i, r, s, t}^{\text {prod }}$ is the part of the productivity that evolves over time as a state variable. This part is known to

\footnotetext{
${ }^{8}$ One of the robustness checks reported in Table 6 will remove this assumption.
} 
domestic owners and potential (foreign) buyers of the firm. The term $\varepsilon_{i, r, s, t}$ is an i.i.d. zero mean deviation of productivity, unknown to the owner of the firm and to potential buyers. Both terms, however, are unobservable to the econometrician. If $A_{i, r, s, t}^{p r o d}$ is a constant productivity advantage (or disadvantage) of firm $i$ it could be captured using a firm fixed effect $\phi_{i}$ in an otherwise standard panel estimation of equation (3). However, if the variable $A_{i, r, s, t}^{\text {prod }}$ varies over time, as firms can be purchased with little obstacles by foreign multinationals, the optimal choice of acquisition is likely to be a function of productivity $A_{i, r, s, t}^{p r o d}$. This would induce correlation between the term $A_{i, r, s, t}^{\text {prod }}$ and $F_{i t}$, undermining the consistency of least squares estimates of $\alpha_{s}$ and $\beta_{s}$ even if we include firm fixed effects.

The problem of endogenous acquisition of firms is similar to the one of endogenous exit of firms addressed by Olley and Pakes (1996) and Pavcnik (2001), or the one of endogenous choice of inputs addressed by Levinsohn and Petrin (2003). In our dataset we need to pay particular attention to endogeneity of acquisitions, which happened frequently in the 90's. On the other hand, sluggishness of the European labor market guarantees that the innovations to the variable $k_{i t}$ are likely uncorrelated with the contemporary innovations to $A_{i, r, s, t}^{p r o d}$ as it probably takes a firm at least one year to adjust its capital and the labor inputs.

Our method, a variation on the procedure proposed by Levinsohn and Petrin (2003), relies on the fact that the optimal choice of variable inputs of a firm, such as the material inputs used, $m_{i t}$ (for which data are available) depend monotonically on the firm's productivity $A_{i, r, s, t}^{\text {prod }}$ and on its capital per worker $k_{i t}$. Therefore, using the fact that $m_{i t}=m\left(A_{i, r, s, t}^{\text {prod }}, k_{i, r, s, t}.\right)$ we can invert the function and express $A_{i, r, s, t}^{\text {prod }}$ as a function $A\left(m_{i t}, k_{i, r, s, t}\right)$. Using a polynomial approximation of $A\left(m_{i t}, k_{i, r, s, t}\right)$ we can substitute this function into (3) absorbing all the variation of the term $A_{i, r, s, t}^{\text {prod }}$ in the error and, therefore, eliminating the correlation with $F_{i t}$. This allows to obtain a consistent estimate of the parameters $\beta_{s}$ in the first stage of the estimation. Then in a second stage, using the assumption that shocks to the productivity variable, $A_{i, r, s, t}^{\text {prod }}-E_{t-1}\left(A_{i, r, s, t}^{\text {prod }}\right)$, do not affect either the current capital/labor ratio, $k_{i, r, s, t}$, or the past choice of ownership $F_{i t-1}$ we can use this moment restriction to implement a GMM consistent estimator of $\alpha_{s}$. The details of this method are described in Levinsohn and Petrin (2003).

The crucial assumption of this approach is that it relies on the contemporary correlation between use of materials and productivity shocks of a firm to "absorb" from the unobserved term the part 
correlated with the variable $F_{i t}$, hence providing consistent estimates of $\beta_{s}$. We then use the assumption that capital and labor inputs take a period to adjust to productivity shocks (differently from material input use that adjusts immediately) in order to get consistent estimates of the parameter $\alpha_{s}$.

A similar method using investments, rather than material inputs, could be used to correct for the sample selection of firms due to exit, as proposed by Olley and Pakes (1996). Unfortunately we do not have investment data for the year previous to the one in which a firm exits the dataset. Partially mitigating this problem, however, we run some probit regressions of the probability that a firm exits the sample on capital per worker and other firm-characteristics. We do not find any significant relationship with observable variables. Therefore, rather than drastically reducing the sample size in order to include a balanced panel of firms, we simply use the whole sample assuming that the inclusion (or exclusion) in our sample is not correlated with unobserved characteristics that may affect productivity.

A final way of estimating total factor productivity relies on efficiency frontier estimation techniques. These techniques estimate the distance of a firm's technology from the production frontier. Essentially, this amounts to the estimation of:

$$
y_{i, r, s, t}-\bar{y}_{s r t}=\alpha_{s}\left(k_{i, r, s, t}-\bar{k}_{s r t}\right)+\beta_{s} F_{i t}+u_{i t}+\varepsilon_{i t}
$$

where $u_{i t}$ follows a truncated normal distribution on the positive range measuring the technical inefficiency and $\varepsilon_{i t}$ is the usual symmetrically distributed white noise error term.

The term $u_{i t}$ is identified as a firm fixed effect with an industry-specific estimated growth trend:

$$
u_{i t}=u_{i} \cdot \exp \left(\kappa_{s} \cdot t\right)
$$

where $u_{i}$ and $\kappa_{s}$ and their standard errors are estimated by a maximum likelihood method. The measure of TFP obtained with this method, $A_{i, r, s t}^{\text {front }}$ is defined as $A_{i, r, s, t}^{\text {front }}=u_{i t}+\varepsilon_{i t} .{ }^{9}$ The advantage of this estimation method is that it explicitly assumes the existence of a technological frontier specific to a sector and year and identifies the productivity of firms as their 'relative' distance from

\footnotetext{
${ }^{9}$ While $u_{i t}$ alone is the estimated inefficiency term, the TFP of a plant should also include the zero-mean deviations $\varepsilon_{i t}$. I
} 
this frontier. This is appealing as the local presence of highly productive FDI's can be considered as a factor that helps a firm to catch-up to the technological frontier reducing its relative inefficiency.

\section{The Data}

We have gathered and organized two novel datasets containing balance sheets, accounting and ownership information for a large sample of manufacturing firms in Italy and Germany. The database of Italian firms is an unbalanced panel of about two hundred thousand observations over the time period 1992-1999. The number of firms increases over time and reaches about 40 thousand units in 1999. This database includes, in principle, the whole universe of Italian manufacturing firms. However, early in the sample, small firms are underrepresented, revealing that the coverage of data collection has broadened over time. We exclude year 1992 and 1993 from the analysis as missing data seem too large a fraction of the universe.

The database of German firms covers a $2 \%$ sample of German manufacturing firms and about $16 \%$ of German manufacturing employment. It is therefore, much smaller than the Italian database and concentrates on large firms. The data consists of an unbalanced panel of about 800 manufacturing firms per year over the time period 1993-1999. We checked, however, that the dataset is representative in the regional and time dimension (more in the Appendix).

Both datasets have firms as a unit of observation and balance sheets are the source of data. This implies that the productive activity is assigned to the headquarters and not to the actual location of plants. In our case, the problem is largely mitigated, because we use unconsolidated balance sheet information both for Italy and Germany. This implies that only plants that are not independent legal entities are mis-classified regionally. As these plants are usually small relative to the headquarters and we are interested in total factor productivity (rather than volume of activity), the resulting error will be small.

We maintain the econometric analysis for the Italian and German sample separate, because of differences in industry codes, regional size and other definitions of variables between the two datasets. Also, the German data capture a particularly interesting period, as the formerly isolated East Germany was suddenly exposed to Western technology and FDI penetration. In contrast Italy did not experience any major shock in the nineties but we can consider the decade as characterized 
by slow-growth and slow convergence in regional productivity. As the data are new we describe each dataset and present summary statistics in the rest of this section ${ }^{10}$.

\subsection{Italian Firms}

Our database of Italian firms, obtained with the assistance of the Centro Studi Luca d'Agliano ${ }^{11}$, merges the AIDA database of Bureau van Dijk (which contains balance sheet information) and the multinational firm database Reprint of Politecnico di Milano (which contains ownership information). The observations on firms' balance sheets include data on the number of employees, on wage cost, on the values of sales, on the value of materials used as intermediates, on fixed assets of the company, on the industrial sector, its location and its name. The industry code contains 23 manufacturing sectors. Our definition of region, for Italy, is the so-called "Provincia", a rather small administrative unit containing one main city. There are 103 of them in Italy and they correspond to the "NUTS3" aggregation level in the Eurostat territorial classification.

The summary statistics of the main variables for three representative years within our sample (1994, 1996 and 1998) are reported in Table1a. We define the universe of foreign-owned firms as those firms with a strictly positive fraction of voting rights held by foreigners. Typically the share of voting rights held by foreigners will be large enough to exercise control of the firm. In 1998 total employment in foreign firms was 402,704 employees. The large increase in the number of firms covered by the database from 1994 to 1998 and the decrease in their average size (for domestic firms) is due to the fact that an increasing number of smaller firms is included over time. We eliminated from the data those observations that contain outliers in the levels and growth rates of the firm variables. The appendix describes the selection procedure carefully.

Foreign-owned firms tend to have higher value added per worker, to be more capital intensive and pay larger wages than domestic firms. On average, therefore, foreign-owned firms have higher labor productivity than domestic ones and may be the source of the Veblen-Gerschenkron effect for Italian firms. We should keep in mind, however, that the summary statistics presented in Table 1a conceal large differences across sectors and localities. Foreign-owned firms are concentrated mostly in large urban areas in the north-west of the country (mostly Milano, Torino and Genova) and

\footnotetext{
${ }^{10}$ Further details on the construction of the variables are contained in the Appendix.

${ }^{11}$ We are grateful to Giorgio Barba Navaretti for making this data available to us.
} 
around Rome. They are present, however in smaller concentration in most of the provinces. This uneven distribution of FDI is illustrated in Figure 1. The Figure captures with different shades of grey the different percentages of employed workers in foreign-owned firms across provinces. Darker colors correspond to higher FDI concentration. The map also shows the boundaries of provinces.

\subsection{German Firms}

Our database of German firms, obtained by retrieving past and current data releases by Bureau van Dijk, is a subset taken from the database Amadeus 200,000 containing only large manufacturing firms with more than 200 employees or more than 10 Million Deutsche Marks Assets or more than 10 Million Deutsche Marks Sales. The dataset of German firms contains the same variables as the Italian one, i.e. employment, wage costs, sales, fixed assets, material costs and information on the location, sector and ownership of the firm. For Germany, given the smaller number of firms included in the sample (about 800), we are forced to use a fairly broad regional aggregation, i.e. the 16 Bundesländer ${ }^{12}$ to have a sufficient number of domestic and foreign-owned firms in each region. Given the large size of firms included in the German dataset we believe that it is appropriate to consider larger regions as potential receivers of spillovers, because large firms are likely to hire workers and have interactions in a larger "basin of attraction" than smaller firms. Twenty manufacturing sectors (defined according to the U.S. SIC code) are included. Three sectors are excluded because of small-sample concerns. We investigate in the Appendix how representative these data are using aggregate data of Statistisches Bundesamt (2000) and Deutsche Bundesbank (2001) as comparison. Consistently with the definition used for Italy, we define as foreign-owned all firms which reported some foreign ownership of their voting shares ${ }^{13}$. We define also Western-owned firms in East Germany as multinational firms ${ }^{14}$. Companies of Treuhandanstalt, the privatization agency of the German government, are considered local firms.

Table 1b shows the summary statistics for the German dataset. Notice the larger size of domestic and foreign-owned firms and their higher productivity and capital intensity relative to Italian firms. Even in this case labor productivity and wages are significantly higher in foreign-owned firms than in

\footnotetext{
${ }^{12}$ The Bundesländer correspond to the NUTS1 classification of EUROSTAT.

${ }^{13}$ Relevant for ownership is the reported ultimate owner. Only if no information is available on the ultimate owner, the direct ownership determines the nationality of a firm.

${ }^{14}$ Criscuolo and Martin (2002) show that UK-owned multinationals in the UK have the same productivity advantage over UK firms with no plants abroad as foreign-owned multinationals.
} 
domestic ones confirming the idea that the last group enjoys technological advantage over domestic firms.

We construct the variable FDIdensityr,t as the share of total workers employed by foreignowned firms in Lander $r$. Data on FDI employment were obtained from Deutsche Bundesbank (2001) ${ }^{15}$ and total employment is obtained from Statistisches Bundesamt $(2000)^{16}$.

Similarly to Italy, the majority of foreign-owned firms is located in large metropolitan areas. Figure 2 illustrates the density of foreign-owned firms across Bundesländer using darker colors for higher densities. The density of FDI is highest in the Bundesländer containing Berlin, the political center, Frankfurt, the financial center, and Hamburg, the major German port. While hosting most of the foreign firms these regions are not necessarily those receiving the largest benefits from them because the technological lead of FDI over domestic firms can be smaller than in less developed regions.

\section{$5 \quad$ Estimation Results}

\subsection{Replicating Standard Spillover Regressions}

In this section, we replicate a basic regression used by Aitken and Harrison (1999), among others, in order to investigate into spillovers from FDI. Table 2 reports the results from a regression of firm-level output on firm-level inputs (Labor, Capital and Materials) and on FDIdensity $, s, t$. The regression includes only domestic firms and assumes a log linear production function. We report the estimates of the elasticity of output to the three inputs as well as the effect of FDI density in three specifications for each country. The first three specifications (I-III) are estimated on Italian data while specifications IV to VI are estimated on German data.

Column I and IV include the mentioned explanatory variables plus sector and time fixed effects. Such regressions yields a significant coefficient on the FDIdensity variable. ${ }^{17}$ This result is qualitatively and quantitatively similar to those obtained in studies of other countries. FDIdensity has

\footnotetext{
${ }^{15}$ We thank Heinz Herrmann of Deutsche Bundesbank for providing these unpublished data.

${ }^{16}$ There are some incompatibilities between Amadeus, the data of Deutsche Bundesbank (2001) and the data of Statistisches Bundesamt (2000) such as the definition of sectors, the definition of FDI and the reporting obligations by firm size.

${ }^{17}$ We use heteroscedasticity robust standard errors rather than clustered standard errors despite the Moulton problem caused by the FDI density variable to keep results comparable with the previous literature.
} 
a positive and significant coefficient on the domestic firm's TFP.

Column II and V replace the sector fixed effects with firm fixed effects and this renders the coefficient of FDIdensity insignificant. This is exactly what Aitken and Harrison (1999) found in a similar specification using their data on Venezuelan firms (see their Table 2, specification 3 and 4). Next, Aitken and Harrison (1999) show that regional control variables such as average regional wage-costs (that proxies for human capital, unobserved differences of labor quality or other location factors) also render the density variable insignificant. We replicate their result in columns III and VI by including average regional wages. We also run a regression that includes regional fixed effects (not reported in the table). Also in this case the FDI density variable has no significant effect on productivity of domestic firms. Finally, we allow elasticities to vary by sector and we include all firms in our regression (domestic and foreign-owned) controlling for ownership. The estimates of the effect of FDI on productivity in those specifications (not reported in the table and available upon request) are very similar to those presented in Table 2 and not significant.

Summing up, the FDI density variable is positively correlated with domestic firms' productivity growth at the regional level, but after controlling for regional characteristics such correlation disappears. Regional factors that are responsible for growth may also be responsible for the presence of FDI inducing a spurious correlation. This does not mean, however, that no spillovers from FDI exist. Instead, the FDI density variable may not be a good proxy for the intensity of technological spillovers in the first place. We explore in the remaining of this section the role of productivity advantage of FDI in spurring productivity growth of domestic firms.

\subsection{Comparing Total Factor Productivity Measures}

We estimate total factor productivity of a firm, $A_{i, r, s, t}$, using the five methods presented in section 3. The first method, called "Superlative Index", implements equation (2). We use data on the share of wage costs relative to value added, in each firm and on average, to calculate the elasticity of value added to labor (and to capital). This method has the advantage of by-passing any issue of endogeneity of inputs and ownership as it is not estimation-based. The following four methods are estimation-based, instead. In particular, we implement regression (3) using simple OLS estimation (once data are cleaned of their time-sector component), or controlling for firm fixed effects or accounting for endogeneity of ownership using the Levinsohn and Petrin (2003) method. Finally, 
the last columns of Table $3 \mathrm{a}$ and $3 \mathrm{~b}$ report the estimates obtained using the efficiency frontier estimation and allowing for "firm-specific" inefficiencies.

We report the estimated elasticities of value added to capital, by industry (parameters $\alpha_{s}$ of expression 2 and 3) for Italy (Table 3a) and Germany (Table 3b) using each method. The index-based measures of $\alpha_{s}$, reported in the first column of Table 3a and 3b, vary by sector and cluster around 0.4-0.5. They seem somewhat large, relative to the previously estimated elasticities (Pavcnick 2002, Levinsohn and Petrin, 2003) which, for several manufacturing sectors are in the range $0.10-0.20$. The estimation-based elasticities, reported in column 2, 3, 4 and 5 of Table $3 \mathrm{a}$ and $3 \mathrm{~b}$ are much closer to this range.

In spite of some variation depending on the method used, the coefficients obtained using different estimation methods seem rather robust and precisely estimated. As an example, elasticity of output to capital in the Food Sector for Italy range between 0.22 and 0.26 . The base estimate for the same sector in the U.S. reported by Levinsohn and Petrin (2003) is 0.24. For textiles our estimates range between 0.12 and 0.15 and theirs is 0.18 and for wood products our estimates range between 0.15 and 0.19 and theirs is 0.19 .

The standard errors on these estimates range between 0.01 and 0.03 . They are asymptotically heteroscedasticity consistent for the OLS and the Fixed-effect method, while in the Levinsohn and Petrin (2003) and efficient frontier estimation we report the bootstrapped standard errors. On average parameters are more precisely estimated in the Italian case as we have many more observations. In particular, the standard errors of the estimates using the Levinsohn and Petrin (2003) method could be very large in the German sample. However, except for few cases, the parameters for German sectors are also reasonable and close to the range estimated for Italian firms.

In spite of the variation in the estimates of factor elasticity, the five methods produce TFP estimates that are remarkably similar to each other. Table 4 reports the correlation across firms and time of these five measures for Italian and German data. The TFP values obtained using the three estimation methods (OLS, FE, Levinsohn and Petrin and efficient frontier) have extremely high correlation with each other, in the range 0.98-0.99. However the index-based values are also highly correlated to the other measures exhibiting a correlation coefficient of 0.7-0.8. This reassures us in the interpretation of each of these measures as a proxy of actual productivity of a firm. 


\subsection{Evidence on the Veblen-Gerschenkron Effect}

In this section we estimate specification (1) to capture spillover effects. We use the Blundell and Bond (1998) one-step system GMM estimator which improves efficiency upon the Arellano and Bond (1991) GMM difference estimator (especially in panels with short time dimension) by using past levels as well as time differences to instrument the lagged level of firm TFP. This method provides consistent estimates (as opposed to OLS or fixed effects that produce biased estimates in panels due to the correlation between the lagged dependent variable and the error term). The GMM estimates on Italian data are based on a restricted set of instruments, while the German estimates employ all dependent variables, lags and lagged differences of the dependent variable as instruments. The dynamic panel estimations include firm random effects.

The results of the dynamic panel estimation are reported in Table 5a for Italy and in Table 5b for Germany. Each column of each table uses a measure of productivity obtained from one of the five different methods described above. The reported standard errors are heteroscedasticity and autocorrelation consistent. Still, the GMM-estimator assumes no autocorrelation of second order or higher. A second order AR-test (AR2) investigates this assumption. Finally, the validity (exogeneity) of instruments is tested using a heteroscedasticity consistent Hansen-J test. In principle, the Blundell-Bond estimator is still consistent, when the data are non-stationary, but Binder et al. (2003) show that the small sample properties become unfavorable. Therefore, we apply a simple test suggested by Bond et al. (2002) to test for unit roots in our data. We are able to reject the null hypothesis of non-stationarity for each of the variables included in our regressions (the tests statistics are reported in the Appendix). Moreover, all the auxiliary AR2-tests cannot reject the assumption of no autocorrelation of order two at the $5 \%$ level and no Hansen-J test rejects the assumption of exogeneity of instruments at the $5 \%$ confidence level in both tables. Therefore, exogeneity of lagged differences and of instruments cannot be rejected. ${ }^{18}$ The coefficients of interest are those on the "Productivity-Gap" variable $\left(\bar{A}_{r, s, t-1}^{F D I}-A_{i, r, s, t-1}\right)$ and on the density of multinationals in the regional industry, (FDI density rst $_{\text {). }}$.

The first result emerging consistently from our estimates is that the "Productivity-Gap" variable has always a positive and significant effect on productivity growth of domestic firms. This is true

\footnotetext{
${ }^{18}$ One caveat remains: The Hansen-J test is extremely sensitive to small changes in specifications and to inclusion/exclusion of variables.
} 
both for Italian and German firms and for each measure of productivity. Since the coefficient $\beta_{2}$ of equation (1) is positive and significant, the productivity gap between local multinationals and the domestic firms acts as a growth-promoting factor, revealing a positive Veblen-Gerschenkron effect. Such positive effect does not stem from general convergence of firms' productivity, because we control for lagged productivity. The positive effect of local catch-up due to the presence of highly productive foreign firms is estimated above and beyond that mechanism. Moreover, by construction, the variable $A_{i, r, s, t}$ is cleaned of any time-sector fixed effects so that the correlation between productivity gap and domestic firm growth cannot be due to a sector-specific business cycle effect, or FDI concentrations in some specific sectors.

Quantitatively, the Veblen-Gerschenkron effect is of comparable size for German and Italian firms. A $10 \%$ productivity gap between a domestic firm and the local multinational firms translates into 4-6\% larger productivity after one year for the average domestic firm. This is a very large effect. Given the similarity of the estimates between the Italian and the German case, we tend to believe that the coefficients capture a similar mechanisms at work in the two countries. In spite of the similarity of the coefficient estimates, German firms probably received larger benefits from FDI (through this channel) because of the larger initial productivity gap of the eastern domestic firms and therefore faster catch-up.

The second result emerging from our estimates is that the density of foreign-owned firms in the sector-region has generally not a significant effect on productivity growth of domestic firms in most of the specifications of Tables 5a and 5b. When the effect is significant, however, it is positive. As argued above this may reflect the fact that the FDI density is largest in urban areas which are centers of economic activity, where the productivity of domestic firms is already high and hence less affected by technological spillovers. Instead, in less developed regions the larger productivity gap with foreign-owned firms is the main cause of technological catch-up even if the density of FDI is not too large.

Finally, we tested that $\left(\beta_{1}-\beta_{2}\right)<1$ which ensures conditional convergence of firm's productivity to a common sector-year growth path. This restriction is never rejected at any standard confidence level. Our estimates, therefore, can be interpreted as follows: while some technological factors specific to sectors determine a common rate of productivity growth, firms that are located in the same region as highly productive FDI, tend to converge to higher relative productivity levels as they 
benefit from technological transfer. To the contrary the concentration of foreign firms in the sectorregion seems to have only a smaller and insignificant effect on relative productivity of domestic firms. This is consistent with local technological spillovers that depend on the "technological gap" between FDI and domestic firms, rather than on the density of the last ones. As found above, FDI can be concentrated in advanced regions, where there is not much scope for technological learning, while fewer highly productive foreign companies have a strong impact on less developed regions.

\subsection{Robustness of the Veblen-Gerschenkron Effect}

We performed several robustness checks of our results. Our main goal is to confirm that the Veblen-Gerschenkron effect on local firms' productivity growth remains positive and significant to changes in the specifications and to the inclusion of control variables. We summarize these robustness checks in Table 6 by reporting only the estimates and the standard errors for the coefficient of the "Productivity Gap" that has been the focus of our analysis. We report only the specifications using the TFP measures based on the superlative index (Sup. Ind.) and on the firm fixed effect production function estimation (FE), because all the "estimation-based" methods (OLS, FE, Levinson and Petrin and Frontier) produced very similar results. Columns one and two of Table 6 report the coefficients estimates using Italian data, columns three and four report the estimates using German data.

Specification (1) reports the basic estimates, taken from column one and two of Tables 5a (for Italy) and 5b (for Germany). Specification (2) omits the variable that captures the density of employment in foreign-owned firms in the regional sector. It is clear from the reported results that including that variable or excluding it does not make any difference. This is true also when we use other estimation methods (such as Arellano and Bond, in specification (3) and (4)). The productivity-gap variable seems the only important determinant of spillovers from FDI's. Specification (3) checks the robustness of the results to the estimation method. Often these dynamic panel methods, based on GMM estimation, are very sensitive to the choice of instruments. The Arellano and Bond estimator uses past values of the productivity level as instruments for the current changes of productivity. The point estimates of the Veblen-Gerschenkron effect increase somewhat using this method, however, the difference is less than two standard deviations from the effects estimated using the Blundell and Bond method except for column one where the difference is somewhat larger. 
More interestingly, in specification (5) we include in the regression the change in firm's employment as a control variable to check whether the positive catch-up effect of local firms to multinational productivity was simply achieved by trimming inefficiently employed workers (i.e. through a decrease in employment). While productivity growth has a significant negative association with employment growth, revealing in equilibrium the potential effects of workers' selections on productivity growth, the Veblen-Gerschenkron effect is still positive and significant, and not much reduced. For German firms the coefficient estimates are between 0.3 and 0.55 (std. errors 0.06-0.09) while for Italian firms they are in the range 0.4-0.6 (std. errors 0.02). In this case, the Hansen J-test of exogeneity of instruments could not always reject endogeneity of the predetermined variables at the standard levels of significance. While auxiliary tests may occasionally fail, this hardly affects the magnitude or significance level of the estimated coefficients ${ }^{19}$. As the point estimates are very stable and those tests very sensitive, we regard the overall evidence as favorable to the existence of strong Veblen-Gerschenkron effects.

Finally, in specification (6) we performed a more demanding robustness check by re-estimating the TFP measures (in the OLS, FE and Levinsohn and Petrin Method) without imposing constant returns to scale in the firm's production function. For the superlative Index method we need to assume constant returns to scale (CRS) in order to identify the TFP so we cannot perform this check. The estimates of the elasticity of output to capital (not reported) obtained without imposing CRS are often quite different from before. Remarkably, however, the TFP measures are highly correlated to those previously estimated and the estimates of the magnitude of the VeblenGerschenkron effect are closely aligned with what we found earlier. Namely, for Italy we obtain coefficients in the range 0.4-0.6 (table 6 reports only the coefficient based on FE-TFP which is equal to 0.49) and for Germany in the range 0.3-0.6 (again in Table 6 only the one based on FE-TFP is reported and it is equal to 0.57 ).

\section{Conclusion}

Technological catch-up is a powerful force behind the development of countries and regions and it is likely to be an important cause of convergence in income per capita across OECD countries. FDI

\footnotetext{
${ }^{19}$ Using German data no auxiliary test ever failed. Only using Italian data we encountered occasional problems of rejection.
} 
are channels of diffusion of technological knowledge. It seems natural, therefore, to inquire whether the impact of FDI on productivity of local firms works through a catching-up mechanisms that depends on geographical proximity and on the technological gap. Interestingly, this has not been done yet. Our article uses two novel datasets of Italian and German firms to test this hypothesis. Rather than the trite specification in which the presence of FDI's has an effect on local productivity, we test the more articulate hypothesis that technological advantage of foreign firms, coupled with proximity in location and similarity in specialization, helps local firms to grow faster. Technological advantage of foreign-owned firms is better captured by the average productivity advantage of FDI in a sector-region rather than by their concentration. Our empirical test confirms this theory. As our story is based on productivity catch-up and TFP growth we implement in the paper several different methods to measure firms TFP, each with some advantages and limits. This is also a relatively original contribution and, in our case, it establishes that index-based measures of firm-level productivity are highly correlated with estimation based measures. In particular, the simple cost-based superlative index or a simple Fixed Effect estimation of the production function produce, for our purposes, similar results than the more sophisticated methods that account for firm heterogeneity or for endogeneity of foreign ownership. 


\section{Tables and Figures}

Table 1a: Summary Statistics for Italian Manufacturing Firms

\begin{tabular}{llll||lll}
\hline Ownership: & \multicolumn{3}{l||}{ Foreign } & \multicolumn{3}{l||}{ Domestic } \\
\cline { 2 - 7 } Year: & 1994 & 1996 & 1998 & 1994 & 1996 & 1998 \\
\hline \hline Value Added per Employee & 123.69 & 128.67 & 128.61 & 106.08 & 110.41 & 101.88 \\
Fixed Assets per Employee & 99.91 & 85.18 & 96.85 & 77.34 & 74.39 & 73.91 \\
Material Inputs per Employee & 314.46 & 323.77 & 334.24 & 305.37 & 295.65 & 280.84 \\
Average Wage Cost/ Employee & 71.48 & 69.77 & 70.82 & 56.66 & 57.85 & 56.43 \\
Number of Employees per firm & 256 & 332 & 356 & 72 & 62 & 54 \\
Number of firms & 354 & 898 & 832 & 9858 & 30469 & 36738 \\
\hline
\end{tabular}

Source: AIDA dataset, merged with Politecnico di Milano data. Values are in Millions of 1999 Italian Lire. The dataset has been purged from outliers and from firms exhibiting unusual changes in capital and employment from one year to the other.

Table 1b: Summary Statistics for German Manufacturing Firms

\begin{tabular}{lccc||ccc}
\hline Ownership: & \multicolumn{3}{c||}{ Foreign } & \multicolumn{3}{c}{ Domestic } \\
\cline { 2 - 7 } Year: & 1994 & 1996 & 1998 & 1994 & 1996 & 1998 \\
\hline \hline Value Added per Employee & 279.52 & 248.86 & 296.43 & 196.65 & 214.95 & 239.21 \\
Fixed Assets per Employee & 133.36 & 149.66 & 160.18 & 151.37 & 181.50 & 204.76 \\
Material Inputs per Employee & 397.39 & 392.51 & 458.43 & 240.98 & 275.20 & 330.39 \\
Average Wage Cost/ Employee & 91.46 & 97.50 & 103.70 & 82.15 & 89.23 & 95.93 \\
Number of Employees per firm & 1646 & 1414 & 1311 & 1769 & 1406 & 1331 \\
Number of firms & 203 & 226 & 212 & 653 & 574 & 556 \\
\hline
\end{tabular}

Source: Amadeus Dataset. Values are in thousands of 1999 Deutsche Marks. The dataset has been purged from outliers and from firms exhibiting unusual changes in capital and employment from one year to the other. 
Table 2: Standard Spillover Regressions for Italy and Germany

\begin{tabular}{l|ccc|ccc}
\hline \hline Country & \multicolumn{3}{|c|}{ Italy } & \multicolumn{3}{c}{ Germany } \\
\hline \hline Specification & OLS & Firm & Regional & OLS & Firm & $\begin{array}{c}\text { Regional } \\
\text { Control }\end{array}$ \\
\hline \hline & & FE & Control & & $(\mathrm{I})$ & $(\mathrm{V})$ \\
\hline \hline \multirow{2}{*}{$\ln \left(L_{i, t}\right)$} & $0.21^{* *}$ & $0.21^{* *}$ & $0.21^{* *}$ & $0.29^{* *}$ & $0.25^{* *}$ & $0.29^{* *}$ \\
& $(0.001)$ & $(0.001)$ & $(0.001)$ & $(0.009)$ & $(0.027)$ & $(0.009)$ \\
$\ln \left(K_{i, t}\right)$ & $0.03^{* *}$ & $0.03^{* *}$ & $0.03^{* *}$ & $0.07^{* *}$ & $0.02^{* *}$ & $0.07^{* *}$ \\
& $(0.000)$ & $(0.000)$ & $(0.000)$ & $(0.005)$ & $(0.01)$ & $(0.005)$ \\
$\ln \left(M_{i, t}\right)$ & $0.75^{* *}$ & $0.75^{* *}$ & $0.74^{* *}$ & $0.62^{* *}$ & $0.62^{* *}$ & $0.61^{* *}$ \\
& $(0.001)$ & $(0.001)$ & $(0.001)$ & $(0.009)$ & $(0.030)$ & $(0.009)$ \\
$F D I d e n s i t y$ \\
& $0.03^{* *}, t$ & -0.002 & -0.004 & $0.03^{* *}$ & -0.06 & 0.0006 \\
\hline \hline Average & $(0.003)$ & $(0.003)$ & $(0.003)$ & $(0.008)$ & $(0.03)$ & $(0.01)$ \\
Regional Wage & - & - & $0.002^{* *}$ & & - & $0.002^{* *}$ \\
\hline \hline Sector Fixed Effects & Yes & No & Yes & Yes & No & Yes \\
Time Fixed Effect & Yes & Yes & Yes & Yes & Yes & Yes \\
Region Fixed Effects & No & No & No & No & No & No \\
Firm Fixed Effects & No & Yes & No & No & Yes & No \\
No.Obs. & 162023 & 162023 & 161692 & 3702 & 3702 & 3623 \\
$R^{2}$ & 0.98 & 0.98 & 0.98 & 0.97 & 0.99 & 0.97 \\
\hline
\end{tabular}

Dependent Variable: $\ln \left(Y_{i t}\right)$, natural logarithm of sales of domestic firms.

$* *=$ significant at the $5 \%$ level, $*=$ significant at the $10 \%$ level.

Heteroskedasticity-robust standard errors in parentheses 
Table 3a: Production Function Parameters Estimates for Italy by Sector

\begin{tabular}{|c|c|c|c|c|c|c|c|c|c|}
\hline $\begin{array}{l}\text { Estimation } \\
\text { Method: }\end{array}$ & \multirow{2}{*}{$\begin{array}{c}\text { Superlative } \\
\text { Index } \\
\text { coef.s.e. }\end{array}$} & \multicolumn{2}{|c|}{$\overline{\overline{\text { OLS }}}$} & \multicolumn{2}{|c|}{$\begin{array}{c}\text { Firm } \\
\text { Fixed Effect }\end{array}$} & \multicolumn{2}{|c|}{$\begin{array}{l}\text { Levinsohn- } \\
\text {-Petrin }\end{array}$} & \multicolumn{2}{|c|}{$\begin{array}{l}\text { Eff. } \\
\text { Frontier }\end{array}$} \\
\hline \multirow[b]{2}{*}{ Sector (ATECO definitions) } & & $\overline{c \text { coef }}$ & s.e. & $\overline{c o e f}$ & s.e. & $\overline{c o e f}$ & s.e. & $\overline{c o e f}$ & s.e. \\
\hline & & & & & & & & & \\
\hline Food and Kindred Products & 0.47 . & 0.22 & 0.05 & 0.25 & 0.01 & 0.26 & 0.04 & 0.22 & 0.01 \\
\hline Tobacco & n.a. n.a & n.a. & n.a. & n.a. & n.a. & n.a. & n.a. & n.a. & n.a. \\
\hline Textile & 0.42 . & 0.12 & 0.01 & 0.15 & 0.01 & 0.15 & 0.01 & 0.13 & 0.00 \\
\hline Apparel & 0.40 & 0.17 & 0.01 & 0.21 & 0.02 & 0.21 & 0.01 & 0.18 & 0.01 \\
\hline Leather and Shoes & 0.38 & 0.17 & 0.01 & 0.19 & 0.02 & 0.16 & 0.02 & 0.18 & 0.01 \\
\hline Lumber and Wood Products & 0.41 & 0.19 & 0.02 & 0.15 & 0.01 & 0.19 & 0.03 & 0.16 & 0.01 \\
\hline Paper Products & 0.44 & 0.19 & 0.01 & 0.16 & 0.02 & 0.22 & 0.02 & 0.17 & 0.01 \\
\hline Printing-Publishing & 0.38 & 0.08 & 0.01 & 0.17 & 0.02 & 0.15 & 0.02 & 0.13 & 0.01 \\
\hline Oil Refineries & 0.53 & 0.21 & 0.01 & 0.16 & 0.03 & 0.25 & 0.06 & 0.18 & 0.02 \\
\hline Chemical & 0.47 & 0.10 & 0.01 & 0.17 & 0.01 & 0.23 & 0.03 & 0.13 & 0.01 \\
\hline Plastics & 0.43 & 0.17 & 0.01 & 0.19 & 0.02 & 0.18 & 0.01 & 0.18 & 0.01 \\
\hline Stone, Clay, Glass, Cement & 0.40 & 0.16 & 0.01 & 0.20 & 0.01 & 0.19 & 0.01 & 0.17 & 0.01 \\
\hline Primary Metals & 0.43 & 0.17 & 0.01 & 0.13 & 0.02 & 0.11 & 0.02 & 0.15 & 0.01 \\
\hline Fabricated Metals & 0.38 & 0.14 & 0.01 & 0.18 & 0.01 & 0.15 & 0.01 & 0.16 & 0.00 \\
\hline Mechanical Machinery & 0.37 & 0.11 & 0.01 & 0.15 & 0.01 & 0.07 & 0.02 & 0.13 & 0.00 \\
\hline Computers & 0.37 & 0.06 & 0.02 & 0.17 & 0.03 & 0.05 & 0.06 & 0.11 & 0.02 \\
\hline Electric Machinery & 0.38 & 0.13 & 0.01 & 0.15 & 0.01 & 0.09 & 0.04 & 0.14 & 0.01 \\
\hline Communication Equipment & 0.39 & 0.09 & 0.01 & 0.19 & 0.02 & 0.17 & 0.03 & 0.13 & 0.01 \\
\hline Precision Equipment & 0.38 & 0.11 & 0.01 & 0.17 & 0.01 & 0.19 & 0.04 & 0.13 & 0.01 \\
\hline Auto & 0.38 & 0.20 & 0.01 & 0.13 & 0.01 & 0.14 & 0.04 & 0.16 & 0.01 \\
\hline Other Transportation & 0.38 & 0.14 & 0.01 & 0.16 & 0.02 & 0.16 & 0.05 & 0.14 & 0.01 \\
\hline Furnitures & 0.38 & 0.12 & 0.01 & 0.20 & 0.02 & 0.20 & 0.02 & 0.15 & 0.00 \\
\hline Repair and Recycling & 0.46 & 0.27 & 0.02 & 0.20 & 0.04 & 0.23 & 0.05 & 0.18 & 0.02 \\
\hline
\end{tabular}

The estimated coefficient in each column is the elasticity of value added to the stock of physical capital, assuming constant returns to scale in the production function.

First Column: Superlative index numbers, see main text for calculations. Standard error is zero, because the value is calculated, not estimated.

Second and Third Column: OLS and fixed firm effects estimates of the log-linear production function. Standard errors are hetheroskedasticity consistent.

Fourth Column: Levinsohn-Petrin Estimates, described in detail in the main text. Standard errors are bootstrapped.

Fifth Column: Efficient Frontier estimates. Std errors are bootstrapped. 
Table 3b: Production Function Parameter Estimates for Germany by Sector

\begin{tabular}{|c|c|c|c|c|c|c|c|c|c|}
\hline $\begin{array}{l}\text { Estimation } \\
\text { Method: }\end{array}$ & \multirow{2}{*}{$\begin{array}{c}\begin{array}{l}\text { Superlative } \\
\text { Index }\end{array} \\
\text { coef.s.e. }\end{array}$} & \multicolumn{2}{|c|}{$\overline{\mathrm{OLS}}$} & \multicolumn{2}{|c|}{$\begin{array}{c}\text { Firm } \\
\text { Fixed Effect } \\
\end{array}$} & \multicolumn{2}{|c|}{$\begin{array}{l}\text { Levinsohn- } \\
\text {-Petrin }\end{array}$} & \multicolumn{2}{|c|}{$\begin{array}{l}\text { Eff. } \\
\text { Frontier }\end{array}$} \\
\hline Parameter & & $\overline{c \text { coef }}$ & s.e. & $\overline{c \text { coef }}$ & s.e. & $\overline{c \text { coef }}$ & & 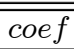 & s.e. \\
\hline & & & & & & & & & \\
\hline Food and Kinc & 0.68 & 0.28 & 0.03 & 0.18 & 0.03 & 0.20 & 0.14 & 0.21 & 0.02 \\
\hline Tobacco & n.a. . n.a. & n.a. & n.a. & n.a. & n.a. & n.a. & n.a. & n.a. & n.a. \\
\hline Textile & 0.45 & 0.12 & 0.04 & 0.05 & 0.04 & 0.07 & 0.07 & 0.09 & 0.03 \\
\hline Apparel & 0.62 & 0.20 & 0.05 & 0.11 & 0.14 & 0.30 & 0.17 & 0.06 & 0.05 \\
\hline Lumber and Wood Products & 0.45 & 0.20 & 0.04 & 0.16 & 0.05 & 0.38 & 0.13 & 0.18 & 0.03 \\
\hline Furnitures and Fixtures & 0.46 & 0.07 & 0.10 & 0.09 & 0.12 & 0.08 & 0.15 & 0.10 & 0.08 \\
\hline Paper products & 0.54 & 0.23 & 0.03 & 0.20 & 0.10 & 0.02 & 0.09 & 0.22 & 0.04 \\
\hline Priniting and Publishing & 0.56 & 0.26 & 0.09 & 0.06 & 0.12 & 0.04 & 0.17 & 0.04 & 0.04 \\
\hline Chemicals & 0.58 & 0.21 & 0.06 & 0.01 & 0.08 & 0.19 & 0.16 & 0.20 & 0.10 \\
\hline Petroleum Refining & 0.73 & 0.04 & 0.02 & 0.16 & 0.03 & 0.09 & 0.07 & 0.11 & 0.01 \\
\hline Rubber and Plastics & 0.46 & 0.24 & 0.04 & 0.52 & 0.11 & 0.19 & 0.20 & 0.23 & 0.08 \\
\hline Stone, Clay, Glass, Concrete & 0.5 . & 0.31 & 0.02 & 0.31 & 0.04 & 0.23 & 0.01 & 0.16 & 0.04 \\
\hline Primary Metals & 0.43 & 0.20 & 0.04 & 0.13 & 0.05 & 0.27 & 0.09 & 0.29 & 0.03 \\
\hline Fabricated Metals & 0.39 & 0.32 & 0.01 & 0.22 & 0.05 & 0.22 & 0.07 & 0.15 & 0.02 \\
\hline Industrial Machinery and Computer & 0.42 & 0.20 & 0.01 & 0.18 & 0.03 & 0.16 & 0.08 & 0.11 & 0.04 \\
\hline Electric Machinery & 0.43 & 0.15 & 0.04 & 0.14 & 0.05 & 0.07 & 0.11 & 0.19 & 0.02 \\
\hline Transportation equipment & 0.40 & 0.28 & 0.03 & 0.28 & 0.14 & 0.08 & 0.15 & 0.12 & 0.05 \\
\hline Precision Instruments & 0.41 & 0.19 & 0.01 & 0.18 & 0.03 & 0.20 & 0.04 & 0.21 & 0.04 \\
\hline Miscellaneous Manufacturing & n.a.. n.a & n.a. & n.a. & n.a. & n.a. & n.a. & n.a. & n.a. & n.a. \\
\hline Leather products & n.a. . n.a. & n.a. & n.a. & n.a. & n.a. & n.a. & n.a. & n.a. & n.a. \\
\hline
\end{tabular}

The estimated coefficient in each column is the elasticity of value added to the stock of physical capital, assuming constant returns to scale in the production function.

First Column: Superlative index numbers, see main text for calculations. Standard error is zero, because the value is calculated, not estimated.

Second and Third Column: OLS and fixed firm effects estimates of the log-linear production function. Standard errors are hetheroskedasticity consistent.

Fourth Column: Levinsohn-Petrin Estimates, described in detail in the main text. Standard errors are bootstrapped.

Fifth Column: Efficient Frontier estimates. Std. errors are bootstrapped. 
Table 4: Correlation between different TFP Measures

\begin{tabular}{||l||lllll||}
\hline \hline \multicolumn{7}{|c||}{ ITALIAN FIRMS } \\
& Sup. Index & Lev.Pet. & FE & OLS & Eff.Front. \\
\hline \hline Sup.Index & 1 & & & & \\
Lev.Pet. & 0.841 & 1 & & & \\
FE & 0.859 & 0.998 & 1 & & \\
OLS & 0.799 & 0.994 & 0.991 & 1 & \\
Eff.Front. & 0.821 & 0.997 & 0.996 & 0.999 & 1 \\
\hline \hline \multicolumn{7}{|c||}{} & GERMAN FIRMS & & & \\
& Sup. Index & Lev.Pet. & FE & OLS & Eff.Front. \\
\hline \hline Sup.Index & 1 & & & & \\
Lev.Pet. & 0.708 & 1 & & & \\
FE & 0.713 & 0.976 & 1 & & \\
OLS & 0.723 & 0.981 & 0.974 & 1 & \\
Eff.Front. & 0.716 & 0.984 & 0.987 & 0.993 & 1 \\
\hline \hline
\end{tabular}

The measures of firm-level TFP are calculated in differences from the sector-period. Each method is described in detail in the text. 


\section{Table 5a}

\section{Dynamic Panel Estimation, Italy}

\begin{tabular}{l|ccccc}
\hline \hline Productivity & Superlative & $\begin{array}{c}\text { Firm } \\
\text {-Index }\end{array}$ & $\begin{array}{c}\text { OLS } \\
\text { Eeasures }\end{array}$ & \multicolumn{5}{c}{$\begin{array}{l}\text { Levinsohn } \\
\text {-Petrin }\end{array}$} & $\begin{array}{l}\text { Eff. } \\
\text { Frontier }\end{array}$ \\
\hline Specification & $0.97^{* *}$ & $0.58^{* *}$ & $0.53^{* *}$ & $0.56^{* *}$ & $0.54^{* *}$ \\
\hline \hline \multirow{2}{*}{$A_{i, s, r, t}$} & $(0.04)$ & $(0.03)$ & $(0.03)$ & $(0.03)$ & $(0.03)$ \\
& $0.65^{* *}$ & $0.44^{* *}$ & $0.42^{* *}$ & $0.43^{* *}$ & $0.43^{* *}$ \\
Productivity Gap & $(0.02)$ & $(0.02)$ & $(0.02)$ & $(0.02)$ & $(0.02)$ \\
& 0.06 & -0.02 & -0.02 & -0.02 & -0.02 \\
$(\text { FDI density) })_{r, s, t}$ & $(0.03)$ & $(0.03)$ & $(0.03)$ & $(0.03)$ & $(0.03)$ \\
Sector/year-Effects & Yes & Yes & Yes & Yes & Yes \\
Number of Observations & 32462 & 36057 & 36057 & 36057 & 36057 \\
\hline \hline AR(1)-Test & $-27.47^{* *}$ & $-29.02^{* *}$ & $-27.98^{* *}$ & $-28.51^{* *}$ & $-28.36^{* *}$ \\
AR(2) - Test & 1.17 & 0.76 & 0.33 & 0.51 & 0.48 \\
Hansen $-J-$ Test & 1.82 & 6.05 & 6.53 & 6.48 & 6.34 \\
$(p-$ value $)$ & $(0.61)$ & $(0.11)$ & $(0.09)$ & $(0.09)$ & $(0.10)$ \\
\hline
\end{tabular}

Dependent variable is $A_{i, s, r, t+1}$, the TFP of firm $i$ in region $r$ and sector $s$ for year $t+1$, calculated according to several different methods.

$A_{i, s, r, t}$ :TFP of firm $i$ in region $r$ and sector $s$ for year $t$, calculated according to several different methods.

Productivity Gap: difference in productivity between the average productivity of a foreign-owned firm in region $r$ and sector $s$ in year $t$ and domestic firm $i$ at time $t$. Strict exogeneity assumed.

$(F D I \text { density })_{r, s, t}$ : Share of workers employed by foreign-owned firms in region $r$ and sector $s$ in year $t$. Strict exogeneity assumed.

$A R(2)$ - Test: Test statistic for the restriction that two-period lagged productivity levels are exogenous instruments for current changes in productivity

Hansen $-J-$ Test : Test of exogeneity of the predetermined and instrumental variables.

$* *=$ Significant at the $1 \%$ level; $*$ significant at the $5 \%$ level

Errors in parenthesis are clustered by firms. 


\section{Table 5b}

\section{Dynamic Panel Estimation, Germany}

\begin{tabular}{|c|c|c|c|c|c|}
\hline $\begin{array}{l}\text { Productivity } \\
\text { Measures }\end{array}$ & $\begin{array}{c}\text { Superlative } \\
\text {-Index }\end{array}$ & $\begin{array}{r}\text { Firm } \\
\text { Fixed Effect }\end{array}$ & $\begin{array}{c}\text { OLS } \\
\text { Estimates }\end{array}$ & $\begin{array}{l}\text { Levinsohn } \\
\text {-Petrin }\end{array}$ & $\begin{array}{l}\text { Eff. } \\
\text { Frontier }\end{array}$ \\
\hline Specification & \multicolumn{5}{|c|}{ Blundell-Bond Estimator } \\
\hline$A_{i, s, r, t}$ & $\begin{array}{l}0.94^{* *} \\
(0.11)\end{array}$ & $\begin{array}{r}0.99^{* *} \\
(0.13)\end{array}$ & $\begin{array}{r}1.08^{* *} \\
(0.14)\end{array}$ & $\begin{array}{l}1.03^{* *} \\
(0.18)\end{array}$ & $\begin{array}{r}1.05^{* *} \\
(0.13)\end{array}$ \\
\hline Productivity Gap & $\begin{array}{r}0.34^{* *} \\
(0.06)\end{array}$ & $\begin{array}{l}0.59^{* *} \\
(0.10)\end{array}$ & $\begin{array}{r}0.67 * * \\
(0.11)\end{array}$ & $\begin{array}{r}0.64^{* *} \\
(0.11)\end{array}$ & $\begin{array}{r}0.65^{* *} \\
(0.11)\end{array}$ \\
\hline$(F D I \text { density })_{r, s, t}$ & $\begin{array}{r}0.23 \\
(0.24)\end{array}$ & $\begin{array}{r}0.48 \\
(0.33)\end{array}$ & $\begin{array}{r}0.46 \\
(0.30)\end{array}$ & $\begin{array}{l}0.68^{*} \\
(0.30)\end{array}$ & $\begin{array}{r}0.44 \\
(0.31)\end{array}$ \\
\hline Sector/year-Effects & Yes & Yes & Yes & Yes & Yes \\
\hline Number of Observations & 1236 & 1285 & 1291 & 1225 & 1291 \\
\hline AR(1)-Test & $-4.80^{* *}$ & $-3.15^{* *}$ & $-2.99^{* *}$ & $-4.01^{* *}$ & $-3.01^{* *}$ \\
\hline$A R(2)-T e s t$ & 0.69 & 0.10 & -0.11 & 0.95 & -0.11 \\
\hline $\begin{array}{c}\text { Hansen }-J-\text { Test } \\
(p-\text { value })\end{array}$ & $\begin{array}{l}20.06 \\
(0.39)\end{array}$ & $\begin{array}{l}11.40 \\
(0.91)\end{array}$ & $\begin{array}{l}11.41 \\
(0.91)\end{array}$ & $\begin{array}{c}7.51 \\
(0.99)\end{array}$ & $\begin{array}{l}11.44 \\
(0.91)\end{array}$ \\
\hline
\end{tabular}

Dependent variable is $A_{i, s, r, t+1}$, the TFP of firm $i$ in region $r$ and sector $s$ for year $t+1$, calculated according to several different methods.

$A_{i, s, r, t}$ :TFP of firm $i$ in region $r$ and sector $s$ for year $t$, calculated according to several different methods.

Productivity Gap: difference in productivity between the average productivity of a foreign-owned firm in region $r$ and sector $s$ in year $t$ and domestic firm $i$ at time $t$. Strict exogeneity assumed.

$(F D I \text { density })_{r, s, t}$ : Share of workers employed by foreign-owned firms in region $r$ and sector $s$ in year $t$. Strict exogeneity assumed.

$A R(2)$ - Test: Test statistic for the restriction that two-period lagged productivity levels are exogenous instruments for current changes in productivity

Hansen $-J-$ Test : Test of exogeneity of the predetermined and instrumental variables.

$* *=$ Significant at the $1 \%$ level; * significant at the $5 \%$ level

Errors in parenthesis are clustered by firms. 


\section{Table 6}

\section{Estimates of the Veblen-Gerschenkron Effect, Robustness Checks.}

\begin{tabular}{|c|c|c|c|c|}
\hline Country & \multicolumn{2}{|c|}{ Italy } & \multicolumn{2}{|c|}{ Germany } \\
\hline Method to calculate the TFP: & Sup. Ind. & $\mathrm{FE}$ & Sup. Ind. & $\mathrm{FE}$ \\
\hline (1) Basic Blundell-Bond & $\begin{array}{c}0.65^{* *} \\
(0.02)\end{array}$ & $\begin{array}{c}0.44^{* *} \\
(0.02)\end{array}$ & $\begin{array}{c}0.34^{* *} \\
(0.06)\end{array}$ & $\begin{array}{c}0.59^{* *} \\
(0.10)\end{array}$ \\
\hline (2) Omitting FDIdensity & $\begin{array}{c}0.65^{* *} \\
(0.02)\end{array}$ & $\begin{array}{c}0.44^{* *} \\
(0.02)\end{array}$ & $\begin{array}{c}0.35^{* *} \\
(0.07)\end{array}$ & $\begin{array}{c}0.64^{* * *} \\
(0.10)\end{array}$ \\
\hline (3) Arellano-Bond & $\begin{array}{c}0.85^{* *} \\
(0.09)\end{array}$ & $\begin{array}{c}0.44^{* *} \\
(0.06)\end{array}$ & $\begin{array}{r}0.41^{* *} \\
(0.13)\end{array}$ & $\begin{array}{c}0.72^{* *} \\
(0.18)\end{array}$ \\
\hline (4) Arellano-Bond omitting FDIdens & $\begin{array}{c}0.85^{* *} \\
(0.09)\end{array}$ & $\begin{array}{c}0.45^{* *} \\
(0.06)\end{array}$ & $\begin{array}{r}0.41^{* *} \\
(0.13)\end{array}$ & $\begin{array}{c}0.70^{* * *} \\
(0.18)\end{array}$ \\
\hline (5) Controlling for Empl. Growth & $\begin{array}{r}0.63^{* *} \\
(0.02)\end{array}$ & $\begin{array}{l}0.42^{* *} \\
(0.02)\end{array}$ & $\begin{array}{r}0.32^{* *} \\
(0.06)\end{array}$ & $\begin{array}{c}0.55^{* *} \\
(0.09)\end{array}$ \\
\hline (6) Not imposing CRS in production & n.a. & $\begin{array}{c}0.49^{* *} \\
(0.02)\end{array}$ & n.a. & $\begin{array}{c}0.57^{* *} \\
(0.10) \\
\end{array}$ \\
\hline
\end{tabular}

Std. error in parentheses. $*=$ significant at the $5 \%$ level, $* *==$ significant at the $1 \%$ level.

The table reports only the estimated coefficient on the variable "Productivity Gap". Each cell corresponds to the result of a different regression.

Specification (1): Basic specification using the Blundell-Bond efficient estimator. The estimates are those reported in the first and second column of Table 5a (for Italy) and 5b (for Germany).

Specification (2): Basic specification without including the variable FDIdensity

Specification (3): Estimates performed using the original Arellano and Bond estimator

Specification (4): Estimates performed using the original Arellano and Bond estimator, not including the variable FDIdensity

Specification (5): Basic specification using the Blundell-Bond efficient estimator and including employment growth as explanatory variable at the firm level. Employment variable assumed pre-determined (not strictly exogenous).

Specification (6): The TFP estimates in the first stage of the econometric procedure have been obtained without imposing constant returns to scale (in capital and labor) of the production function. 
Figure 1

C oncentration of FD I relative to D om estic F irm s, Italy 1998

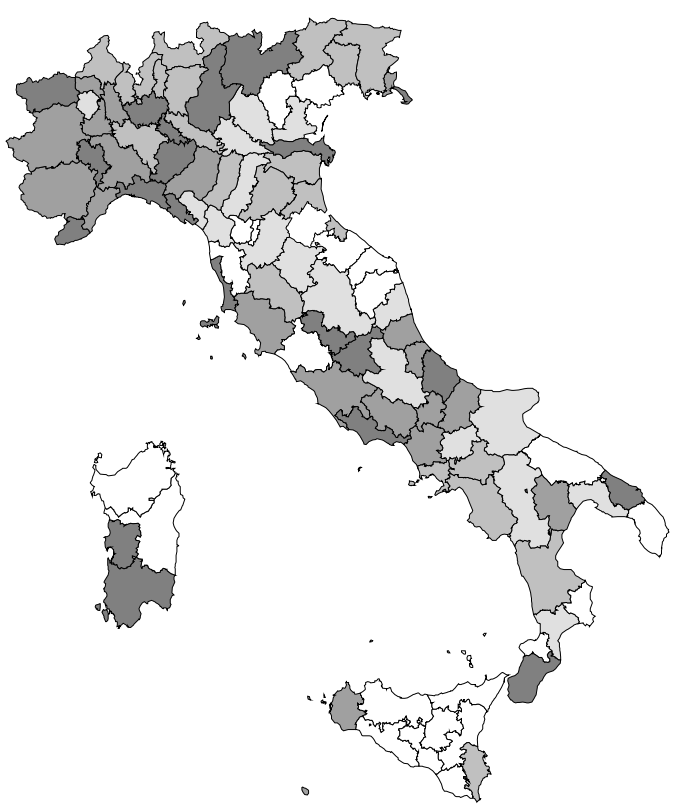

Note: The $m$ ap shows the concentration of FD I calculated as share of w olkers em ployed in foreign-ow ned firm s in a Province in year 1998. The shades of gray (darker shades denotes higher concentration) are five and intervals are spaced so that regions are equally distributed am ong them (roughly tw enty provinces per interval).

D ata Source: Reprint of Politecnico dim ilano. 


\section{Figure 2}

C oncentration of FD I relative to D om estic F irm s, G erm any 1998

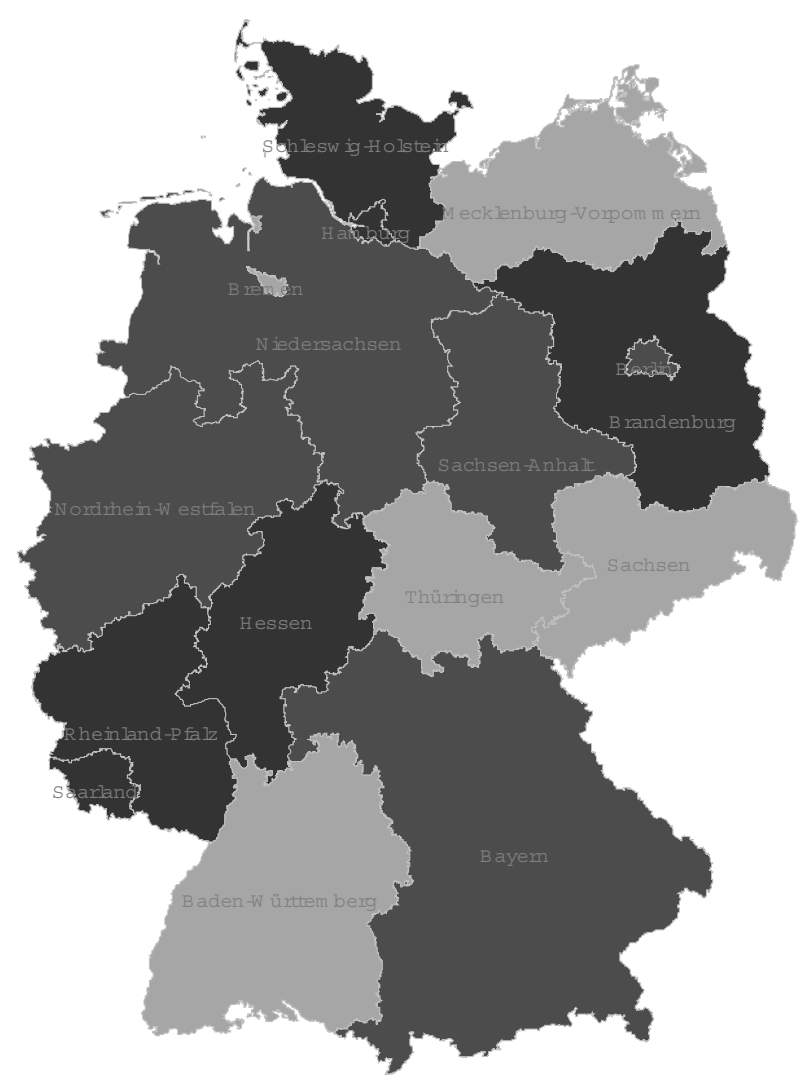

Note: The m ap show s the concentration of FD I calculated as share of w olkers em ployed in foreign-ow ned firm s in a Bundesländer in year 1998 The shades of gray (darker color denotes higher concentration) are three and intervals are spaced so that Landers are equally distributed am ong them (roughly five Landers per interval).

D ata Source: U npublished D ata of D eutsche B undesbank. 


\section{A Appendix: Data Description}

\section{A.1 Italian firms}

Firm data are from the database AIDA of Bureau van Dijk and are matched with ownership information from the FDI database of Politecnico Milano. Only manufacturing firms are included with information on a two-digit industry code (ATECO), the province name of the firm headquarter, and a dummy for foreign ownership participation. Ownership information is collected biannually and assumed to be persistent in a year previous to a reporting year. Whenever available, unconsolidated balance sheet data are used to avoid as much as possible multi-plant firms, which may have production in regions other than the one where the headquarter is located. In general, Bureau van Dijk does not apply any exclusion criteria. However, very small enterprises appear under-represented. Moreover, the database is growing over time. While in the initial years only large firms are sampled, there is no systematic pattern recognizable according to which sampling strategy the database is enlarged until it reaches full size.

To control for outliers and to keep the database homogenous, we exclude a number of observations according to the following criteria:

1) Observations for which capital stocks or sales data were reported as 0 were excluded; observations for which material costs were larger than sales were excluded; observations for which gross operating profits (sales minus material cost minus wage costs) are larger than $80 \%$ of sales value or smaller than -80\% were excluded. Firms with less than 500000 Lira per employee fixed assets and more than 3 Billion Lira per employee were excluded. These exclusion criteria eliminate outliers.

2) All observations with value added divided by sales smaller than $10 \%$ were excluded. These firms are considered sales firms that are missclassified by Bureau van Dijk as production units.

3) All observations with growth rates of employment, fixed assets per employee, material, and average wage cost per employee ${ }^{20}$ of more than $400 \%$ or less than minus $80 \%$ per year were excluded; These criteria ensure that the structure of a firm does not change largely due to re-organization, re-grouping, or takeovers and firm sales within holding companies;

4) All firms with less than 5 employees were excluded. These firms are too small to be considered manufacturing firms.

\footnotetext{
${ }^{20}$ The wage cost exclusion criterium applies only to superlative index based estimations.
} 
5) For superlative index based estimations observations with a labor cost share in value added of more than 0.99 or less than 0.01 , and average wage costs per employee (and year) of less than 10 Mill. Lira and more than 500 Billion Lira were also excluded. Some average wage cost data may be flawed, since there may be a mismatch between the date of reporting of employees and the period over which wage costs are added. Also, restructuring of firms during the reporting period may be a cause for outliers.

Finally, part-time work is not appropriately counted. Reassuringly, however, while the "cleaning" of the data reduces the sample by about 20\% (from 209,934 to 166,550 observations) our coefficient estimates are not sensitive to the exclusion criteria.

We checked representativeness, using ISTAT census for 1996 and 1991. Unfortunately, the industry codes of the census and of our firm database are incompatible so that we can only compare the regional dimension. In 1996 our firm database covers $56 \%$ of manufacturing emplyment and its distribution across provinces calculated using our firm database or ISTAT census data is very similar (correlation of 0.93).

\section{A.2 German firms}

Firm level data are from the Amadeus 200,000 database of Bureau van Dijk. This database is updated in real time on-line. We took data in March 2001. Bureau van Dijk eliminates all observations which are older than 5 years. We completed the dataset by using an old CD-ROM from 1999. ${ }^{21}$ The firm matching between the two datafiles is incomplete, because the firm identification code changed slightly in some cases. We have made a case by case evaluation if in doubt. We have also run consistency checks on location information and adjusted 43 observations. All firms without ownership information in the dataset are considered local owners. This is common practise for the database. Ownership information is available but not in every year. We assume that ownership status is persistent in the years previous to reporting and only changes at the year of reporting. Foreign owned firms are firms with reported voting rights accruing to at least one ultimate foreign owner. This typically implies a substantial (but not necessarily a majority) share of voting right in foreign hands. For East German firms Western owners are considered as foreigners. Companies

\footnotetext{
${ }^{21}$ We thank Bocconi library for providing us with these data and Bureau van Dijk, office Milan, for giving us special permission for the use of these data.
} 
of Treuhandanstalt - the East German privatization agency - are considered domestically owned. Unconsolidated balance sheet data are used.

The same exclusion criteria that was applied to the Italian data were also applied for the German data. ${ }^{22}$ We exclude, however, all firms with less than 20 employees (rather than 5). As the Amadeus database excludes small firms, those with less than 20 employees are most likely holding companies with large assets and no production workers. Even for Germany the coefficient estimates are not sensitive to changes in the exclusion criteria. Reported industry codes are US-SIC codes. We include only manufacturing firms with US-SIC codes 20-39. All observations without US-SIC code are eliminated. In addition, we exclude for the dynamic panel estimations all sectors with less than 35 observations (SIC21, SIC31, SIC39) to have a reliable sector-specific estimate of the capital share used in TFP calculation.

We also investigated, in greater detail, the representativeness of our German database. Tables and statistics relative to the comparison of our data with Bundesbank data are available from Peri and Urban (2002). Here it is enough to note that the number of sampled firms in our database is rather stable over years (around 900 firms sampled each year), reducing the problem of attrition. Also, while some sectors are over-represented (such as chemicals) due to the larger average size of their firms, the covarage of our database is close to be representative at the regional level.

\section{B Appendix: Panel Unit-Root Tests}

Coefficient estimates in panels with a short and fixed time dimension using the Arellano-Bond method are inconsistent if data have a unit-root, while the Blundell-Bond estimator would have poor small-sample properties (see Binder et al., 2003) with non-stationary data. For this reason we perform a test of unit-root on each measure of productivity and on other variables used in the empirical analysis. Bond et al. (2002) suggest to use the t-statistic from a simple OLS estimator with clustered standard errors. As the estimate is consistent under the null-hypothesis of a unit root but inconsistent under the alternative hypothesis of a stationary time series the t-statistic is distributed as a normal under the null. Based on Monte Carlo evidence this test seems to perform well even in the case of a short time dimension. Using this test we can reject the null hypothesis

\footnotetext{
${ }^{22}$ Nominal values of exclusion criteria are translated with an implicit exchange rate of 1 DEM equal to 1000 Lira.
} 
of unit roots for all variables used in our study. The values of the test statistics for each variable and each dataset are reported in the Table A.1 below.

Table A1

\section{Unit Root Tests}

\begin{tabular}{|l|c|c|c|c|}
\hline \hline Country & \multicolumn{2}{|c|}{ Italy } & \multicolumn{2}{|c|}{ Germany } \\
Variable Name & Test-Statistic & Marginal Probability & Test-Statistic & Marginal Probability \\
$A_{i t}^{\text {sup }}$ & 7.76 & 0.00 & 68.11 .11 & 0.00 \\
$A_{i t}^{F E}$ & 9.00 & 0.00 & 86.71 & 0.00 \\
$A_{i t}^{O L S}$ & 9.07 & 0.00 & 88.56 & 0.00 \\
$A_{i t}^{L P}$ & 9.03 & 0.00 & 87.15 & 0.00 \\
$A_{i t}^{F r o n t}$ & 8.88 & 0.00 & 87.16 & 0.00 \\
$\bar{A}_{r s, t-1}^{F D I}-A_{i, t-1}^{\text {sup }}$ & 7.06 & 0.00 & 52.83 & 0.00 \\
$\bar{A}_{r s, t-1}^{F D I}-A_{i, t-1}^{F E}$ & 9.64 & 0.00 & 74.52 & 0.00 \\
$\bar{A}_{r s, t-1}^{F D I}-A_{i, t-1}^{O L S}$ & 9.16 & 0.00 & 75.41 & 0.00 \\
$\bar{A}_{r s, t-1}^{F D I}-A_{i, t-1}^{L P}$ & 9.32 & 0.00 & 74.88 & 0.00 \\
$\bar{A}_{r s, t-1}^{F D I}-A_{i, t-1}^{F r o n t}$ & 9.38 & 0.00 & 68.91 & 0.00 \\
$F D I d e n s i t y$ rst & 7.37 & 0.00 & 41.36 & 0.00 \\
$\triangle$ employment & 20.93 & 0.00 & 146.07 & 0.00 \\
\hline
\end{tabular}

Remarks: test is based on a cluster regression of $x_{i t}=\beta x_{i t-1}+\varepsilon_{i t}$. The OLS estimate $\beta_{O L S}$ is consistent under the null hypothesis $\beta=1$. The test statistic is simply $\left(1-\beta_{O L S}\right) / s_{O L S}$, where $s e_{O L S}$ is the firm-clustered standard error of $\beta_{O L S}$. This test-stastistic has an asymptotic standard normal distribution. Marginal probability is the probability under which the Ho cannot be rejected. 


\section{References}

Aitken B. and A. Harrison, 1999, Do domestic firms benefit from direct foreign investment? Evidence from Venezuela, American Economic Review, Vol. 89, Issue 3, 605-18.

Arellano, M. and S. Bond, 1991, Some tests of specification for panel data: Monte Carlo evidence and an application to employment equations, Review of Economic Studies, Vol. 58, 277-297.

Audretsch D. and M. Feldman, 1996, R\&D spillovers and the geography of innovation and production, American Economic Review, Vol. 86, Issue 3, 630-640.

Barrios, S., H. Görg and E. Strobl, 2004, Foreign direct investment, competition and industrial development in the host country, European Economic Review, In Press.

Binder, M.,C. Hsiao, and M.H. Pesaran, 2003, Estimation and inference in short panel vector autoregressions with unit roots and cointegration, University of Cambridge DAE Working Paper No.0003.

Blomstrom M., S. Globerman, and A. Kokko, 2001, The Determinants of Host Country Spillovers from Foreign Direct Investment: A Review and Synthesis of the Literature, in: Pain, Nigel ed. "Inward investment, technological change and growth: The impact of multinational corporations on the UK economy" Houndmills, U.K.-New York.

Blomström, M. and A. Kokko,1998, Multinational corporations and spillovers, Journal of Economic Surveys, Vol. 12, Issue 3, 247-277.

Blundell, Richard, and Stephen R. Bond, 1998, Initial conditions and moment restrictions in dynamic panel data models, Journal of Econometrics, Vol. 87, 115-143.

Bond, S., C. Nauges, and F. Windmeijer, 2002, Unit roots and identification in autoregressive panel data models: A comparison of alternative tests, Mimeograph, Institute for Fiscal Studies, London, March 2002.

Branstetter, L., 2001, Are knowledge spillovers international or intranational in scope? Microeconometric evidence from Japan and the United States, Journal of International Economics, Vol. 53, 53-79. 
Cassiman, B., and R. Veugelers, 2002, R\&D cooperation and spillovers: Some empirical evidence from Belgium, American Economic Review, Vol. 92, 1169-84.

Castellani, D., and A. Zanfei, 2003, Technology gaps, absorptive capacity and the impact of inward investments on productivity of European firms, Economics of Innovation and New Technology, Vol. 12, Issue 6, 555-576.

Caves R.E., 1974, Multinational firms, competition and productivity in host-country industries, Economica, Vol. 41, 176-93.

Caves, D.W., L.R. Christensen, and W.E. Diewert 1982, Multilateral comparisons of output, input and productivity using superlative index numbers, The Economic Journal, Vol. 92, 73-86.

Criscuolo, C., and R. Martin, 2002, Multinationals, foreign ownership and productivity in UK businesses, Mimeograph, London School of Economics.

Das, S.,1987, Externalities, and technology transfer through multinational corporations, Journal of International Economics, Vol. 22, 171-182.

Deutsche Bundesbank, 2001, Kapitalverflechtung mit dem Ausland, Statistische Sonderveröffentlichung 10 .

Findlay R., 1978, Relative backwardness, direct foreign investment, and the transfer of technology: A simple dynamic model, Quarterly Journal of Economics, Vol 92, Issue 1, 1-16.

Fosfuri, A., M. Motta and T. Rønde, 2001, Foreign direct investment and spillovers through workers' mobility, Journal of International Economics, Vol. 53, 205-222.

Gerschenkron A.,1952, Economic backwardness in historical perspective, in "The progress of underdeveloped areas", B.F. Hoselitz edition, University of Chicago Press, Chicago IL.

Glass, A.J., and K. Saggi, 1998, International technology transfer and the technology gap, Journal of Development Economics, Vol. 55, 369-398.

Glass, A.J. and K. Saggi, , 2002, Multinational firms and technology transfer, Scandinavian Journal of Economics, Vol. 104, Issue 4, 495-513.

Görg, H. and E. Strobl, 2001, Multinational companies and productivity spillovers: A meta-analysis, Economic Journal, Vol. 111, 723-39. 
Girma S, and H. Görg, 2004, Outsourcing, foreign ownership and productivity: Evidence from UK establishment data, Review of international Economics, forthcoming 2004.

Haddad, M. and A. Harrison, 1993, Are there positive spillovers from direct foreign investment? Journal of Development Economics, Vol. 42, 51-74.

Jaffe A., M. Trajtenberg and R. Henderson, 1993, Geographic localization of knowledge spillovers as evidenced by patent citations, Quarterly Journal of Economics, Vol. 108, Issue 3, 577-98

Keller, W., 1996, Absorptive capacity: On the creation and acquisition of technology in development, Journal of Development Economics, Vol. 49, 199-227.

Keller, W., 2000, From socialist showcase to Mezzogiorno? Lessons on the role of technical change from East Germany's post-World war II growth performance, Journal of Development Economics, Vol. 63, 485-514.

Kinoshita, Y., 2001, R\&D and technology spillovers through FDI: Innovation and Absorptive Capacity, CEPR Discussion Paper, No. 2775 (London).

Kokko A., 1994, Technology, market characteristics, and spillovers, Journal of Development Economics, Vol. 43, 279-293.

Levinsohn, J. and A. Petrin, 2003, Estimating production functions using Inputs to control for unobservables, Review of Economic Studies, Vol. 70, 317-341.

Markusen J and A. Venables, 1999, Foreign direct investment as a catalyst to industrial development, European Economic Review, Vol. 43, 335-356.

Olley S. and A. Pakes, 1996, The dynamics of productivity in the telecommunication equipment industry, Econometrica Vol. 64, Issue 6, 1263-97.

Pavcnik N., 2002, Trade liberalization, exit and productivity improvements; evidence from Chilean plants, Review of Economic Studies, Vol 69, 245-76.

Peri G., 2004, Determinants of knowledge flows and their effect on innovation, Review of Economics and Statistics, forthcoming 2004.

Peri G. and D. Urban, 2002, The Veblen-Gerschenkron effect of FDI in Mezzogiorno and East Germany, Working Paper \# 164, Centro Studi Luca d'Agliano. 
Rodriguez-Clare A., 1993, Multinationals, linkages and economic development, American Economic Review, Vol. 86, issue 4, 852-873.

Shannon, Dale P., and William J. Zeile, 1999. Regional patterns in the location of foreign-owned U.S. manufacturing establishments. Survey of Current Business, May, 8-25.

Sjöholm F., 1999, Technology gap, competition and spillovers from direct foreign investment: Evidence from establishment data, Journal of Development Studies, Vol. 36, Issue 1, 53-73.

Stirböck, Claudia, 2001. Agglomeration tendencies on EU regions: where does capital go? ZEW, Discussion paper no. 01-28.

Statistisches Bundesamt, 2000, Statistik regional, CD-ROM.

Veblen T., 1915, Imperial Germany and the industrial revolution, London, Macmillan.

Wang, J.-Y. and M. Blomström,1992, Foreign investment and technology transfer, European Economic Review, Vol. 36, 137-155. 